\title{
CONTROLLING THE TAX BURDEN OF THE ENTERPRISE IN THE REALITY OF UKRAINIAN LEGISLATION
}

\author{
Ihor Alyeksyeyev, Stepan Paranchuk, Oksana Chervinska \\ Lviv Polytechnic National University, Lviv, Ukraine \\ e-mails: ihor.v.alieksieiev@1pnu.ua; Stepan.V.Paranchuk@1pnu.ua; Oksana.S.Chervinska@1pnu.ua \\ (C) 2018 Ihor Alyeksyeyev, Stepan Paranchuk, Oksana Chervinska \\ This is an open access article distributed under the Creative Commons Attribution-NonCommercial- \\ -NoDerivs license (http://creativecommons.org/licenses/by-nc-nd/3.0/)
}

DOI: 10.15611/fins.2018.1.02

JEL Classification: H22, H25, H32

\begin{abstract}
The essence of the "tax burden" is revealed in the paper. The formulas for the determination of an integral and particular tax burden for businesses, who pay taxes on the common system of taxation, are offered. Some measures of optimization of the tax burden in order to stimulate entrepreneurial activity of domestic enterprises, including local and macroeconomic optimization measures, are proposed. The tax burden on enterprise in the form of tax rates in other countries is also presented.
\end{abstract}

Keywords: tax system, the tax burden, tax planning, tax optimization, tax incentives.

\section{Introduction}

The tax system plays a priority role in ensuring conditions for the functioning of enterprises in any country. Realizing the distribution of the income of taxpayers, the tax system must distribute the tax burden between different economic entities according to the size and type of activities.

The difficulties in functioning of business entities, particularly small and medium ones, in connection with the absence of the perfect tax legislation and any incentives for its development are largely burdened with a high level of taxation. The above mentioned factors determine the relevance of the chosen research.

The questions of evaluation and management of the tax burden of the enterprise are considered by many native scientists, among which are: L.I. Novoselska, T.S. Klebanova, G.S. Jastrebova, A. Sokolovska, J. Dropa, I. Chaban. Despite the existence of many macro-economic methods of determining the level of the tax burden, there is no any unified approach to the definition of this indicator at the micro-level.

The purposes of the research are: the definition of "tax burden", the introduction of the procedure of calculation of the partial and integral index of the tax burden for economic entities, the development of recommendations for its optimization at the micro-level. 


\section{The tax burden on economic entities assessment indicators}

Taxes are one of the main factors of influence of the state on the financial conditions of business entities. The state policy in the field of tax assessment is focused on the maximum use of fiscal functions, while not providing a stable environment for the functioning of enterprises, which is connected with the imperfect legislation and excessive tax burden on them, what leads to heavy damage of their activities or to the concealment of income by the enterprises [Krysovatyi et al. 2015].

At the micro-level the tax burden (tax quota - the taxpayer's share in the income of the payer) means the total number of taxes, fees and other payments in value terms the business entity must pay to the budget and to special funds in accordance with current tax legislation [Chervinska, Koval' (eds.) 2014].

In accordance with the method approved in the "Methodological recommendations on drafting the schedule of planned documentary inspections of business entities" [The Order of STA... 2011], the tax burden (tax quota - share of tax in the net income of the payer) from value added tax (VAT) is defined as the ratio of the value added tax to the added value:

$$
\mathrm{TB} \mathrm{VAT}=(\mathrm{VAT} / \mathrm{AT}) \times 100 \%,
$$

where: TB VAT - a tax burden with VAT, \%; VAT - the value added tax, UAH; AT - added value, UAH.

The value added tax is the main turnover tax that is charged in most countries of the world. It should be considered that the taxation is carried out of the added value itself. Added value is the value that is created in the production process of the products (goods) of a particular enterprise and covers its real contribution to the creation of the value of a specific product.

The added value includes salary of the employees, profits of the enterprise and the depreciation of fixed assets (FA). That is to say, the added value is the gross production or market price of manufactured products minus the value of the consumed raw materials purchased from suppliers including the depreciation for $\mathrm{AF}$, as they actively participate in the creation of the market price of products. This hypothesis is confirmed by scientific researches that have been offered since the Soviet practices and to nowadays. However, using the data contained in the financial statements of enterprises, it is rather hard to evaluate the added value without the necessary knowledge of features of activity of the enterprise, and as a result the tax burden on the basis of its components [Ullubiyeva 2010].

The tax burden - the share of the tax in the pure income of the taxpayer - is the ratio of the amount of income tax that is payable to the budget to the taxable profit of the company for the reporting period. Thus, the formula of the tax burden (the tax quota) from the tax on profits of the enterprise (TB ToP) looks like this:

$$
\mathrm{TB} \text { ToP }=\mathrm{ToP} / \mathrm{TP} \times 100 \% \text {, }
$$


where: ToP - tax on profits of the enterprise, UAH; TP - taxable profit of the enterprise, $\mathrm{UAH}$.

The tax burden on the payer of a single social contribution (SSC) is calculated as follows:

$$
\mathrm{TB} \mathrm{SSC}=\mathrm{SSC} / \mathrm{PC} \times 100 \%,
$$

where: TB SSC - the tax burden on the payer of SSC, \%; PC - the payroll of the company, UAH.

For example, we present the information regarding the calculation of the tax burden on the enterprise according to the given indicators (Table 1).

Table 1. Calculation of the indicator of tax burden of "Rainbow" Ltd.

\begin{tabular}{|c|c|c|c|c|c|c|}
\hline \multirow{2}{*}{ No. } & \multirow{2}{*}{ Indexes } & \multicolumn{4}{|c|}{ Years } & \multirow{2}{*}{ Notes } \\
\hline & & 2013 & 2014 & 2015 & 2016 & \\
\hline 1 & $\begin{array}{l}\text { The rate of value added tax } \\
\text { (VAT), \% }\end{array}$ & 20.00 & 20.00 & 20.00 & 20.00 & \\
\hline 2 & $\begin{array}{l}\text { The amount of value added } \\
\text { tax, thousand UAH }\end{array}$ & 22.54 & 39.4 & 36.17 & 42.65 & \\
\hline 3 & $\begin{array}{l}\text { The amount of the value } \\
\text { added, thousand UAH }\end{array}$ & 141.6 & 187.7 & 217.0 & 325.5 & \\
\hline 4 & $\begin{array}{l}\text { The tax burden on VAT payer, } \\
\%\end{array}$ & 15.9 & 20.9 & 16.7 & 13.1 & $\begin{array}{l}\text { TBVAT }= \\
(\mathrm{VAT} / \mathrm{AV}) \times 100 \%\end{array}$ \\
\hline 5 & The rate of income tax, $\%$ & 19.0 & 18.0 & 18.0 & 18.0 & \\
\hline 6 & $\begin{array}{l}\text { The amount of the tax on pro- } \\
\text { fits (ToP), thousand UAH }\end{array}$ & 6.7 & 0.7 & 30.7 & 45.7 & \\
\hline 7 & $\begin{array}{l}\text { Financial result, net corporate } \\
\text { income, thousand UAH }\end{array}$ & 24.6 & 1.77 & 146.7 & 245.4 & \\
\hline 8 & $\begin{array}{l}\text { The tax burden on the payer } \\
\text { of ToP, } \%\end{array}$ & 27.2 & 39.5 & 20.9 & 18.6 & $\begin{array}{l}\mathrm{TBToP}=\mathrm{ToP} / \mathrm{TP} \times \\
100 \%\end{array}$ \\
\hline 9 & $\begin{array}{l}\text { The SSC rate, \% } \\
\text { (depending on the class } \\
\text { of professional risk) }\end{array}$ & $36.76-49.7$ & $36.76-49.7$ & $36.76-49.7$ & 22.0 & $\begin{array}{l}\text { From } 01.01 .2016- \\
22 \% \text { for individual } \\
\text { entrepreneurs } \\
\text { (without classes of } \\
\text { professional risk) }\end{array}$ \\
\hline 10 & $\begin{array}{l}\text { The amount of SSC, thousand } \\
\text { UAH }\end{array}$ & 17.12 & 58.41 & 96.36 & 72.7 & \\
\hline 11 & $\begin{array}{l}\text { Payroll of the company (PC), } \\
\text { thousand UAH }\end{array}$ & 48.6 & 185.5 & 256.6 & 315.8 & \\
\hline 12 & $\begin{array}{l}\text { The tax burden on the payer } \\
\text { of SSC, } \%\end{array}$ & 35.2 & 31.5 & 37.5 & 23.0 & $\begin{array}{l}\mathrm{TB} \mathrm{SSC}=\mathrm{SSC} / \mathrm{PC} \\
\times 100 \%\end{array}$ \\
\hline
\end{tabular}

Source: [Sokolovska 2006; Dropa 2009]. 
Table 1 shows that the tax burden from certain taxes reaches a significant value, so for the value added tax it varies from 15.9 to $21.9 \%$, for the profit tax of the enterprise - from 20.9 to $39.5 \%$, for single social contribution - from 31.5 to $37.5 \%$. It is caused by high tax rates and different tax bases. In addition, it should be noted that these figures do not take into account the full tax burden (tax pressure) to the company in general, as only three types of taxes are taken into consideration. Other tax payments (national and local taxes and fees) also make up a significant share of total tax payments of the enterprise. In particular, - they are excise and environmental taxes, rental payment, property tax (residential and non-residential), fixed tax, transport and land tax, etc. Single social contribution (SSC), which is included in the costs of the enterprise, in the years 2013-2015 varied from 36.7 to $49.7 \%$, according to the class of professional risk [Sokolovska 2006], and from 01.01 .2016 it is $22 \%$ of the payroll without regard to classes of professional risk.

The formula for calculating the integral index of the tax burden on the basis of payments (TBp) that the company pays operates according to the common system of taxation may be represented as the ratio of the amount of taxes paid to net income from sales:

$$
\mathrm{TBp}=((\mathrm{ToP}+\mathrm{VAT}+\mathrm{ET}+\mathrm{SSC}+\mathrm{OTP}) / \mathrm{NP}) \times 100 \%,
$$

where: $\mathrm{NP}$ - net profit excluding indirect taxes, UAH; ET - excise tax, UAH; SSC single social contribution, UAH; OTP - other tax payments, UAH.

For example, the tax burden on i payments (integral indicator) of LLC "Rayduga" in 2016 will be:

$$
\text { TBp } 2016=((45.7+42.65+72.7) / 245.4) \times 100 \%=65.6 \% .
$$

The proposed indicator is the index of the state of taxation of the company and can be considered as a subject of tax administration as it reflects the tax burden on the enterprise (the share of the tax in relation to the income of the payer), because it is the profit from sales that is the purpose of the enterprise and it gives the opportunity to compare the tax burden on companies in various sectors of the national economy and characterises the general tax share of the sales. The tax burden should be compared with the results of production activities which are the most interesting for entrepreneurs. The measures that will contribute to the optimization of the tax burden on the taxpayer should be divided into local and macroeconomic ones [Novoselska 2013].

The local measures of tax burden optimization concern:

- quality assurance of accounting and control of primary documents, methods of assessment and the procedure of writing off on expenses;

- maximizing the net profit on the market through the efficient use of productive resources that is the object of taxation;

- the implementation of tax planning. 


\section{Tax planning as an effective tool to reduce the tax burden on business}

Tax planning is represented by the situation, when the enterprise-taxpayer can choose the address of taxation and the actual address of the enterprise, its branches and representative offices, optimizing tax rates which can vary in different regions of the country, in addition, the right of the taxpayer is to choose the most optimal legal form and regime of taxation, and also they may independently affect the use of profits and the possibility of obtaining benefits [Atamanenko 2010].

International and domestic tax practice confirms the presence of illegal ways of tax evasion and avoiding payment of taxes. In Ukraine, this practice is based mainly on the use of certain "loopholes" because of the imperfection of the current legislation and violations of the taxation discipline by the payers. It should be noted that the evasion from payment of taxes may be based on some illegal ways [Klebanova, Jastrebova 2009, p. 276].

Tax planning is also an extremely effective tool for lowering the tax burden on the company if it eliminates the illegal evasion of tax payments. Scientifically based and efficient tax planning at the enterprise will help free up funds from taxation, which can be used for investment activities.

The macroeconomic measures of tax burden optimization of the enterprise are as follows:

- the reduction in tax rates that will contribute to the growth of budget revenues by increasing the number of taxpayers and broadening the tax base;

- improving the tax administration system and ensuring the transparency of this process;

- the effective provision of tax incentives to companies, etc.

Reducing the total number of tax benefits contributes to the formation of perfect and equitable tax system by equalizing the tax burden between economic entities with a simultaneous reduction of tax pressure on the tax payers. On the other hand, tax incentives are an effective tool to stimulate investment and innovation activities [Alyeksyeyev 2016].

In connection with the introduction in Ukraine of a new tax reform a number of significant changes were offered in the tax code: tax benefits of income tax for business entities in hotel business, information technology, and power industry were cancelled; the basic rate of income tax on profits from operations with securities and derivatives was set; investment income, interest, discount income, dividends, royalties; the conditions for obtaining tax concessions for the enterprises of fuel and energy complex, water supply and sanitation were revised; from 01.01.2016 a general SSC rate of $22 \%$ was introduced for physical persons - entrepreneurs and for persons conducting independent professional activity (without risk classes), the SSC of 3.6\% retention of employees from the payroll was abolished; the requirements regarding the registration of individuals as payers of VAT were changed, which includes 
the increasing of the total amount from the transactions for the supply of goods, works (services) within 12 calendar months cumulatively, from 300,000 UAH to $1,000,000 \mathrm{UAH}$ (excluding value added tax). This innovation applies to taxpayers subject to the common system of taxation [Monitorymh ekonomichnoho... 2015] and has a positive effect on the improvement of the tax system. Thus, the introduction of the proposed innovations of the tax code increases the competitiveness of enterprises and their investment attractiveness [Maystrenko, Sopko 2014].

\section{Optimization of the tax burden as a factor of stimulating entrepreneurship}

It is obvious that decline of the tax burden on the taxpayer, through the introduction of reasonable tax preference, increases the efficiency of the enterprise. In Ukraine, however, there is no effective mechanism of preferential collection of taxes that weakly stimulates investment activities and often the introduced tax incentives lose their effectiveness.

The information about the tax burden on businesses in Ukraine and other countries in the world in the form of rates of certain taxes from the corporate income tax is shown in Table 2 .

On the basis of data from Table 2 the corporate income tax rates are in the range from 10\% (Bulgaria) to 55\% (UAE). The reason for this are certain directions of tax policy which is implemented in some countries. It should be also noted that in a number of countries (Australia, Austria, Belgium, Bulgaria, Ireland, UAE, Poland, Russian Federation, Romania, France), during the analysed period, the tax rate was stable. In Ukraine, the rate of income tax for the period from 2010 to 2016 dropped from 25 to $18 \%$, which indicates a decrease in the tax burden of enterprises-taxpayers. Reducing of the income tax rates is a European trend. Then, for Belarus the income tax will be reduced to $18 \%$, for Bulgaria to $10 \%$, for Great Britain to $20 \%$, for Canada to $26.5 \%$, for Cyprus to $12.5 \%$, for Romania to $16 \%$, for Hungary to $18 \%$.

Some countries in Europe and Asia used the progressive scale of income tax rates - Japan, United Kingdom, Bulgaria. For example, in the United States the higher rates are applied, if the company obtains high incomes, i.e. becomes monopolist. In Canada, two rates of the income taxation are used - federal and provincial, respectively, the income is paid to the federal and provincial budgets. In Germany, two rates are used: for the income which is retained $-50 \%$ and for the income which is distributed $-36 \%$. When the income is undistributed, the dividends of shareholders are taxed with the income tax. In France there is a tax on the net income, which is determined by taking into account all its operations (difference between income and general expenses).

The foregoing attests that in each country there is a corporate income tax, but its levy has certain features that reflect the state's economic development and its task. 
Table 2. Basic (standard) and progressive rate of the corporate income tax in some countries of the world in 2016

\begin{tabular}{|c|c|c|c|}
\hline No. & Country & Basic (standard) rate, $\%$ & $\begin{array}{c}\text { Progressive / reduced rate, } \\
\%\end{array}$ \\
\hline 1 & UAE & 55.00 & - \\
\hline 2 & USA & 40.00 & $-/ 15 ; 25$ \\
\hline 3 & Japan & 39.30 & $40 / 5.10 ; 23.33$ \\
\hline 4 & Malta & 35.00 & \\
\hline 5 & Belgium & 34.00 & \\
\hline 6 & France & 34.00 & $-/ 24$ \\
\hline 7 & Australia & 30.00 & \\
\hline 8 & Norway & 28.00 & \\
\hline 9 & Sweden & 28.00 & \\
\hline 10 & Canada & 26.50 & $-/ 12$ \\
\hline 11 & Austria & 25.00 & \\
\hline 12 & Denmark & 25.00 & \\
\hline 13 & China & 25.00 & \\
\hline 14 & Czech Republic & 21.00 & \\
\hline 15 & Lithuania & 21.00 & \\
\hline 16 & Great Britain & 20.00 & $25 /-$ \\
\hline 17 & Estonia & 20.00 & \\
\hline 18 & Russian Federation & 20.00 & \\
\hline 19 & Poland & 19.00 & \\
\hline 20 & Slovakia & 19.00 & \\
\hline 21 & Belarus & 18.00 & \\
\hline 22 & Ukraine & 18.00 & \\
\hline 23 & Hungary & 18.00 & \\
\hline 24 & Turkey & 18.00 & \\
\hline 25 & Swizterland & 17.92 & \\
\hline 26 & Romania & 16.00 & \\
\hline 27 & Albania & 15.00 & \\
\hline 28 & New Zealand & 15.00 & \\
\hline 29 & Germany & 15.00 & \\
\hline 30 & Ireland & 12.50 & \\
\hline 31 & Cyprus & 12.50 & \\
\hline 32 & Bulgaria & 10.00 & $15 ; 20 /-$ \\
\hline
\end{tabular}

Source: [Maystrenko, Sopko 2014; Khomutenko 2016].

For Ukraine reducing the nominal tax rate on profit does not affect the rapid development of business, since it is very important to establish the optimal rate, tax base, and the level of tax. The basis for the calculation of income tax in Germany is accounting. Tax reporting statements are prepared on the basis of commercial 
accountability, with adjustment indicators according to the tax legislation. In France, as well as in Germany, the income tax accounting is conducted in accordance with international financial reporting standards. In this way, France has achieved the

Table 3. Basic (standard) and reduced rate of value added tax (VAT) of some countries in the world, 2016

\begin{tabular}{|c|c|c|c|}
\hline No. & Country & Basic (standard) rate, $\%$ & Reduced rate, $\%$ \\
\hline 1 & Hungary & 27 & $5-8$ \\
\hline 2 & Denmark & 25 & - \\
\hline 3 & Croatia & 25 & $13 ; 5$ \\
\hline 4 & Sweden & 25 & $6-12$ \\
\hline 5 & Finland & 24 & $10-14$ \\
\hline 6 & Romania & 24 & 9 \\
\hline 7 & Greece & 23 & 13 \\
\hline 8 & Ireland & 23 & $4.8-9-13.5 ; 0$ \\
\hline 9 & Poland & 23 & $8 ; 5$ \\
\hline 10 & Portugal & 23 & $6-13$ \\
\hline 11 & Slovenia & 22 & 9.5 \\
\hline 12 & Belgium & 21 & 6 \\
\hline 13 & Spain & 21 & $10 ; 4$ \\
\hline 14 & Latvia & 21 & $0-12$ \\
\hline 15 & Lithuania & 21 & $0.5-9$ \\
\hline 16 & Netherlands & 21 & 6 \\
\hline 17 & Czech Republic & 21 & 15 \\
\hline 18 & Austria & 20 & 10 \\
\hline 19 & Bulgaria & 20 & - \\
\hline 20 & Great Britain & 20 & $0-5$ \\
\hline 21 & Estonia & 20 & $0-9$ \\
\hline 22 & Israel & 20 & $8.5 ; 17$ \\
\hline 23 & Ukraine & 20 & $0 ; 7$ \\
\hline 24 & France & 20 & $5.5-10 ; 2.1$ \\
\hline 25 & Italy & 19 & $10 ; 4$ \\
\hline 26 & Cyprus & 19 & 5 \\
\hline 27 & Germany & 19 & 7 \\
\hline 28 & Slovak Republic & 19 & 10 \\
\hline 29 & Malta & 18 & 5 \\
\hline 30 & Russian Federation & 18 & 10 \\
\hline 31 & Luxembourg & 15 & $6 ; 3$ \\
\hline
\end{tabular}

Source: [Ullubiyeva 2010; Narakhuvannya ta splata...; Lytvynenko 2003, p. 224]. 
complete harmonization of accounting and tax legislation owing to the adoption of the improved tax code in 2011. In Lithuania, the income tax is determined on the basis of accounting. The feature of its system is that the income and expenses are recognised in accordance with accounting principles, except for the income, determined on a cash basis. The Ukrainian model of charging income taxes can be improved by borrowing the experience of Lithuania, Germany and France, in particular, owing to the introduction of the rules of financial accounting at the legislative level [Khomutenko 2016].

Comparison of the basic (standard) rates of value added tax in Ukraine and some other countries is shown in Table 3.

Value added tax (VAT) is one of the most common indirect taxes in the world, due to its fiscal and regulatory capacity. VAT provides stable revenues to the state budget, even at the time of instability of the economy because consumers are required to buy a minimum of required amount of goods, including medical supplies, works, services. Value added tax taxes the added value of product or service at any stage of production, and the final will be charged to the consumer. Each country has its own tax system which has the features of the basic (standard) rates, methods of calculation, levy, privileges granting or progressive rates applying. In European countries the basic (standard) rate of VAT (Table 3) is within 15\% (Luxembourg); 27\% (Hungary); 24-25\% (Denmark, Croatia, Sweden, Finland, Romania); 18-23\% in the rest of the countries.

It is known that even under the simplified system of taxation, which has certain positive aspects, enterprises in Ukraine have a significant tax burden due to the high rates of VAT, single social contribution corporate income tax and a single tax. Such situation requires effective measures on the part of the state, in order to reduce the tax burden on the taxpayer for further development of the entrepreneurships and to provide the opportunities to fulfil its socio-economic functions. In accordance with the abovementioned information, this will serve as the subject of further research [Lytvynenko 2003].

Therefore, the tax system of Ukraine has certain problems that require immediate solutions. The administration of tax payments requires improvement, as they inhibit the development of the economy, which creates a threat both to the socio-economic situation and to the economic security of the state.

\section{Conclusions}

Today one of the most important tax and economic directions of the development of the state is the optimization of tax burden on enterprises-taxpayers. When optimizing the tax burden it is necessary to take into account the interests of the state in the greatest possible filling of the budgets and target funds for the higher level of provision of social services and the interests of taxpayers relative to decreasing the tax burden. The most effective optimization of tax burden on economic entities 
can only be achieved with comprehensive carrying out on them local and macroeconomic measures of influence, as well as with the further implementation of relevant tax reforms in Ukraine.

\section{References}

Alyeksyeyev I.V., 2016, Upravlinnya podatkovym navantazhennyam pidpryyemstv, Rehional'na ekonomika. Naukovo-praktychnyy zhurnal Instytutu rehional'nykh doslidzhen' NAN Ukrayiny, no. 4, pp. 145-152.

Atamanenko I.B., 2010, Efektyvnist' metodiv podatkovoho planuvannya, Visnyk Natsional'noho universytetu L'vivs'ka politekhnika, no. 669: Lohistyka, pp. 335-341.

Chervinska O.S., Koval' O.V. (eds.), 2014, Analiz podatkovoho navantazhennya v Ukrayini ta shlyakhy yoho optymizatsiyi, http://nbuv.gov.ua/j-pdf/nvnltu_2014_24.6_49.pdf.

Dropa Y., 2009, Podatkove navantazhennya ta yoho vplyv na ekonomiku Ukrayiny, [in:] Dropa Y., Chaban I., Formuvannya rynkovoyi ekonomiky v Ukrayini, Vyp. 19.

Khomutenko A., 2016, Adaptatsiya zarubizhnoho dosvidu opodatkuvannya prybutku pidpryyemstv do vitchyznyanoyi praktyky, Naukovyy visnyk Odes'koho natsional'noho ekonomichnoho universytetu, no. 7, pp. 112-131, http://nbuv.gov.ua/UJRN/Nv_2016_7_11.

Klebanova T.S., Yastrebova H.S., 2009, Modelyuvannya podatkovoho navantazhennya v umovakh transformatsiynoyi ekonomiky: Monohrafiya, Vydavnychyy dim YNZhEK, Kharkiv.

Krysovatyi A.Y., Mayburov Y.A., Yvanov Yu.B., 2015, Fyskal'nyy federalyzm. Problemy y perspektyvy razvytyya: monohrafyya, Yunyty-Dana, Moskva.

Lytvynenko Y.V., 2003, Osoblyvosti splaty podatkiv v inshykh krayinakh svitu, [in:] Lytvynenko Y.V. (ed.), Podatkova polityka, MAUP, Kyiv.

Maystrenko Y.V., Sopko V.V., 2014, Vykorystannya svitovoho dosvidu obliku podatku na prybutok pidpryyemstv v Ukrayini, pp. 136-139, http://ir.kneu.edu.ua:8080/bitstream/2010/6851/1/Maystrenko.pdf.

Monitorynh ekonomichnoho zakonodavstva. Holovni zminy. Podatky i zbory, http://www.niss.gov.ua/ public/File/monitoring/monitoringpodatkiiyun.pdf.

Narakhuvannya ta splata PDV v Yevropi, http://groshi-v-kredit.org.ua/narahuvannya-ta-splata-pdv-v-evropi.html.

Novoselska L.I., 2013, Metody otsinyuvannya rivnya podatkovoho navantazhennya na pidpryyemstva, Naukovyy visnyk NLTU Ukrayiny: zb. nauk.-tekhn. Prats', Ser.: Ekonomika planuvannya ta upravlinnya v haluzyakh, RVV NLTU Ukrayiny, L'viv, Vyp. 23.7, pp. 239-244.

Sokolovska A.M., 2006, Teoretychni zasady vyznachennya podatkovoho navantazhennya ta rivnya opodatkuvannya ekonomiky, Ekonomika Ukrayiny: polityko-ekonomichnyy zhurnal, no. 7, pp. 4-12.

The Order of STA of Ukraine, no. 190, from 01.04.2011, on approval of methodological recommendations on the drafting of the schedule of planned documentary inspections of business entities.

Ullubiyeva K.K., 2010, Dodana vartist' yak ob'yekt bukhhalters'koho obliku ta baza obkladannya $P D V$, Visnyk ZhDTU 2, http://core.ac.uk/download/pdf/11824138.pdf. 


\section{KONTROLING OBCIĄŻENIA PODATKOWEGO PRZEDSIĘBIORSTWA W REALIACH USTAWODAWSTWA UKRAIŃSKIEGO}

Streszczenie: W artykule określono istotę „obciążenia podatkowego”. Przedstawiono sposoby ustalenia całościowych i szczególnych obciążeń podatkowych dla przedsiębiorstw, które płacą podatki w ramach powszechnego systemu podatkowego. Zaprezentowano pewne, w tym lokalne i makroekonomiczne, środki optymalizacji obciążenia podatkowego w celu pobudzenia działalności przedsiębiorstw krajowych. Przedstawiono również obciążenie podatkowe w formie stawek podatkowych w innych krajach.

Słowa kluczowe: system podatkowy, obciążenie podatkowe, optymalizacja podatkowa, bodziec podatkowy. 